\section{Low-Income Community Solar: Utility Return Considerations for Electric Cooperatives}

Douglas Gagne, Alexandra Aznar

The objective of this short report is to identify project structures that make low-income community solar projects more cost-effective, replicable, and scalable, for electric cooperative and municipal utilities. This report explores the tradeoffs between providing energy bill savings for low-income subscribers and utility project returns, as well as some of the key lessons learned from existing successful lowincome community solar pilot projects.

\section{Introduction}

Community solar ${ }^{l}$ projects are a fast-growing segment of the solar market, expected in a recent GTM Research analysis to grow to a 500-megawatt (MW) annual market by 2019, and account for almost a quarter of the U.S. non- residential PV market over the next five years. ${ }^{2}$ Further, electric cooperatives are expected to "continue to drive the majority of new community solar programs brought online in the long term," due to the large number of cooperative utility customers nationwide. ${ }^{2}$

However, this growth may not include all income segments of society. In a recent study, $73 \%$ of community solar programs required an upfront customer payment, which often excludes low and moderate income (LMI) households without upfront capital or access to credit. ${ }^{3}$ LMI households are often also energy burdened. The Colorado Energy Office defines households as energy burdened if they spend more than $4 \%$ of their annual income on utility bills. ${ }^{4}$ Based on research performed by the U.S. Census and compiled by the Colorado Energy Office, roughly $30 \%$ of households in Colorado are energy burdened, often severely, under this definition.

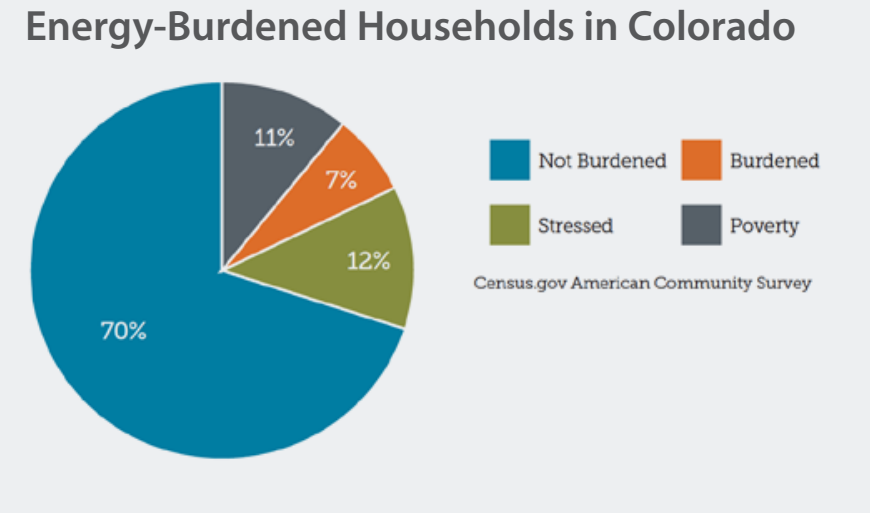

Figure 1. Energy Burden in Colorado ${ }^{5}$

Low-income community solar (LICS) offers a tool to expand customer access to solar energy by reducing or eliminating the upfront cost barrier, and provides more flexibility in payment terms than a traditional solar project. Cooperatives and municipal utilities have often taken the lead in developing LICS projects, due to their greater regulatory flexibility, and are the focus of this analysis.

In order to alleviate the impacts of energy burden on LMI households through solar development, the Colorado Energy Office (CEO) launched its Low-Income Community Solar Demonstration Program in 2015. The CEO awarded a $\$ 1.2$ million grant to GRID Alternatives, a nonprofit organization that implements solar photovoltaic (PV) and energy efficiency projects for lowincome families, to implement the pilot program. The program also generally leveraged matching utility investments. GRID Alternatives partnered with eight Colorado rural electric cooperative utilities to develop the program's portfolio of low-income community solar projects listed in Table 1.

A detailed evaluation of this Demonstration Program, as well as a subscriber-focused analysis and low-income community solar

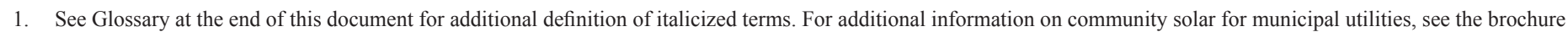
"Lessons Learned: Community Solar For Municipal Utilities" at https://www.nrel.gov/docs/fy17osti/67442.pdf

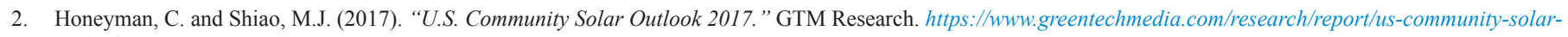
outlook-2017

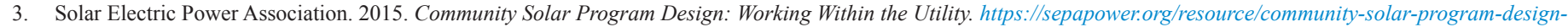
working-within-the-utility/

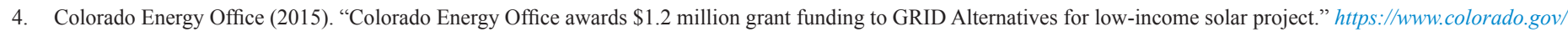
pacific/sites/default/files/atoms/files/Colorado\%20Energy $\% 200$ ffice $\% 20$ awards $\% 20 \% 241.2 \% 20$ million\%20 grant $\% 20$ funding $\% 20$ to $\% 20$ GRID $\% 20$ Alternatives $\% 20$ for $\% 20$ low-income\%20 $\%$ solar\%20project.pdf

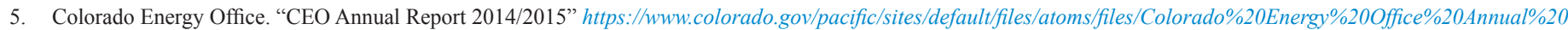
Report\%202014-2015.pdf 
program development best practices, are summarized in the report "Insights from the Colorado Energy Office Low-Income Community Solar Demonstration Project." ${ }^{\prime}$

This report features an in-depth review of the largest project in the program (Poudre Valley Rural Electric Association), a financial analysis of the utility return for six of the projects that provided

Table 1. Summary of CEO LICS Projects

\begin{tabular}{|c|c|c|}
\hline Project Name & $\begin{array}{l}\text { Project } \\
\text { Size }(k W)\end{array}$ & Subscribers \\
\hline $\begin{array}{l}\text { Delta Montrose Electric } \\
\text { Association (DMEA) }\end{array}$ & 151.1 & 43 \\
\hline $\begin{array}{l}\text { Empire Electric Association } \\
\text { (EEA) }\end{array}$ & 26.4 & 7 \\
\hline Fort Collins Utilities (FCU) & 63.6 & 30 \\
\hline Grand Valley Power (GVP) & 36.5 & 10 \\
\hline Holy Cross Energy (HCE) & 144.7 & 45 \\
\hline $\begin{array}{l}\text { Poudre Valley Rural Electric } \\
\text { Association }\end{array}$ & 700 & 140 \\
\hline $\begin{array}{l}\text { San Miguel Power } \\
\text { Association (SMPA) }\end{array}$ & 197.2 & 60 \\
\hline $\begin{array}{l}\text { Yampa Valley Electric } \\
\text { Association (YVEA) }\end{array}$ & 165 & 45 \\
\hline TOTAL & $1,484.5$ & 380 \\
\hline
\end{tabular}

financial data, as well as a discussion of potential LICS project structures for cooperatives and municipal utilities. Although there is significant discussion of utility return in this report, a low-income community solar project might still meet its LMI household savings objectives while not ultimately earning a large return. Reducing the energy burden of LMI households is a primary objective of dedicated low-income community solar. However, projects that generate a slight return, or at least do not result in large financial losses, will ideally enable more cooperatives and municipal utilities to engage in LICS projects without relying on project grants or excess capital.

\section{Demonstration Program Results}

\section{Poudre Valley Rural Electric Association}

The largest project in the Demonstration Program, developed by Poudre Valley Rural Electric Association (PVREA), utilized a utility-led Power Purchase Agreement (PPA)-based project structure.
For its community solar array, PVREA used a unique ownership approach. It utilized one of its taxable subsidiaries to develop and own its system, which allowed it to take advantage of the federal tax incentives. It then passed these incentives through to its tax equity investor in the project, which assisted with project finance. Then PVREA entered into a PPA with this subsidiary that owned the project and sold the power to PVREA. The advantage of this approach is that PVREA avoided a large upfront cost for the system and instead simply paid a certain rate for the solar generation. Then, based on the PPA rate, PVREA established a solar credit rate that meets its customer savings and overall return objectives. PVREA also blended the subscribership to its 1.95-MW community solar array between three groups: non-LMI residential subscribers (39\% of the array), nonprofits (26\%), and low-income subscribers (36\%). Although the traditional subscribers and nonprofits will still save money, they made up $65 \%$ of the array and paid up front for their subscription, which helped to improve the overall economics of the project. LMI subscribers received no-cost four-year agreements, with a guaranteed $30 \%$ savings on their retail energy rate, which was similar to the savings provided by the other utilities under the CEO Demonstration Program. It is also worth noting that PVREA can change the subscription terms under its community solar program in the future, allowing them to fine-tune the exact targeted savings and adjust for future energy market developments. PVREA indicated that the transaction costs associated with pursuing this structure were significant, and that a MW or greater scale project would likely be required to attract interest.

Ultimately, PVREA expects to earn a roughly break-even return on its $700 \mathrm{~kW}$ LMI portion of the community solar project, when compared with its returns under business as usual. This is due to the availability of Renewable Energy Credit (REC) payments, lower project costs due to a larger project size, and PVREA's monetization of the tax incentives. PVREA's expected break-even return is a significant accomplishment, and demonstrates that community solar projects can dedicate large portions of their capacity to LMI subscribers in a cost-effective manner.

In spite of its break-even overall return, there were several challenges that limited the project. The project's economics were limited by its "take-or-pay" arrangement with Tri-State and lack of demand charge savings under its contract. In addition, contacts at PVREA indicated that the project was done on a brownfield site, which added significantly to the overall cost of the project due to extended permitting timelines and land mitigation requirements. PVREA's approach may be subject to regulatory limitations in certain states, but cost-effectively provided a significant benefit for LMI subscribers.

\section{Cooperative-Owned Community Solar}

\section{Methodology}

Financial models were developed for six of the eight utilities in order

6. Colorado Energy Office (2017). "Insights from the Colorado Energy Office Low Income Community Solar Demonstration Project." https://www.colorado. gov/pacific/sites/default/files/Insights $\% 20$ from $\% 20$ the $\% 20$ CEO $\% 20$ LowIncome $\% 20$ Community $\% 20$ Solar\%20Demonstration $\% 20$ Project.pdfGRID $\% 20$ Alternatives $\% 20$ for\%20low-income $\% 20$ solar\%20project.pdf 
to examine their project returns under the community solar projects, as well as under a business-as-usual case (if utilities continued to charge their LMI customers for electricity at retail rates). Data for Fort Collins Utilities was unavailable at the time of analysis. All six of the utilities analyzed were tax-exempt rural electric cooperatives, with project sizes between 26 kilowatts $(\mathrm{kW})$ and $200 \mathrm{~kW}$. In order to protect the business-sensitive financial information of individual utilities, the utility returns were combined into a single weighted average return, which limits the generalizability of the results to future projects.

To compare the projects, we used the net present value (NPV) metric. The NPV metric accounts for the discounted value of future cash flows, and can quantify a net loss where both the cash outlay and cash flows are negative (which was the case for several utilities). To discount the value of future cash flows, a 5\% discount rate was used. ${ }^{7}$ Although cooperative utilities do not have a traditional cost of capital (see call-out box on page 6), this discount rate was approximated based on an interview with one of the utilities, and by using the NYU Stern Cost of Capital dataset, which indicated a $4.6 \%$ cost of equity for utilities (the six utilities included in the analysis did not use debt financing). One shortcoming of the NPV metric is that it is purely financial - ancillary benefits of solar (e.g., air quality, reliability, consumer cost stability) are not included. For LMI customers in particular, the benefit of reduced electricity bills can be significant, allowing households to avoid making difficult decisions about whether to prioritize expenditures on their families' health, or on energy bills.

After defining the weighted average utility return, a sensitivity analysis of the impact of the initial system purchase price, the inclusion of tax incentives, and varying customer discounts was performed in order to quantify the impact of these variables on the future returns of LICS projects.

\section{Colorado Utility Returns Context}

Because Colorado is a regulated power state, the concept of utility return requires additional context. All Colorado utilities can own generation assets, but cooperative utilities primarily rely on wholesale energy providers to generate electricity, and do not typically own many generation assets. Electric cooperatives primarily manage the transmission and distribution infrastructure to deliver the electricity generated by wholesale providers, and recover their expenses from customers through their electric rates. As a result, cooperatives do not recognize profits or losses like a for-profit (i.e., investor-owned) utility would. Therefore, for analysis purposes, any utility returns in this context will be defined as the net-present value of project cash flows, with the disclaimer that the cooperatives' regulatory context may allow them to prioritize financial decisions differently than a for-profit utility would.
The project returns were not compared against other types of energy burden reduction programs, such as weatherization or bill assistance, as this information could not be gathered within the timeframe of this analysis. Future study of the comparative benefit of community solar versus these other programs should be conducted in the future.

\section{Cooperative-Owned Community Solar Results}

These projects were jointly funded by CEO and the participating utilities, but also benefitted from community contributions obtained by GRID Alternatives and from volunteer installation labor (including the low-income subscribers). External project financing was not utilized by the utilities, although one utility did finance its project through an internal $0 \%$-interest loan. All six of the electric cooperatives analyzed are tax-exempt entities, so no tax liabilities or deductions were included in the analysis.

Although the upfront system cost was subsidized by CEO, with the exclusion of one small project that received 100\% CEO funding, the participating utilities paid between $\$ 0.60 /$ watt (W) and $\$ 2.00 / \mathrm{W}$ for the acquisition of the solar systems. Out of the six utilities analyzed, all but one of the projects generated a positive return. The weighted average NPV for the projects was roughly $\$ 118,000$, meaning that the projects will generate $\$ 118,000$ in net income over the course of 20 years, after accounting for the utility's portion of the initial capital cost. The project that did not generate a positive return cost more up front, and also provided the highest discount (52\%) to its LMI subscribers.

Without the CEO funding, all but one of the projects would have resulted in a loss, with a weighted average return of roughly $-\$ 75,000$. The project that would have earned a positive return without CEO subsidy provided a relatively small (15\%) subscriber discount, which may be too small to impact households' energy burden and likely explains much of that project's higher overall return.

The complete transaction structure utilized by the utilities is shown in Figure 2. The utilities' returns from the community solar projects are smaller than their returns under a business as usual case. This is in part because the utilities paid for a portion of the upfront cost of the system, which would not have been required under business as usual. In addition, because the solar generation is used to credit subscribers' bills at a rate below typical utility rates, this results in lower revenues for each kilowatt-hour (kWh) credited. For example, if the utility provides a $0.06 / \mathrm{kWh}$ credit to an LMI household, this equates to $\$ 0.06 / \mathrm{kWh}$ less in utility bill revenues from that subscriber. In summary, despite receiving a grant for a portion of the system cost, these projects were less profitable to utilities than their business as usual case. In addition, for electric cooperatives that rely on Tri-State for wholesale power, Tri-State's energy policies require cooperatives to pay for all of their electricity consumed, even if that consumption is partially met by the community solar project, which further lowered these projects' returns. ${ }^{8}$

7. Damodaran, A.New York University Stern School of Business. "Cost of Capital By Sector(US)" http://people.stern.nyu.edu/adamodar/New_Home_Pagel datafile/wacc.htm

8. Tri-State Policy 115 and 118 :

http://www.lpea.com/pdf/DOE/TriState115.pdf

http://www.southwestchptap.org/Data/Sites/1/documents/states/Tri-State_Policy_ Summary.pdf 


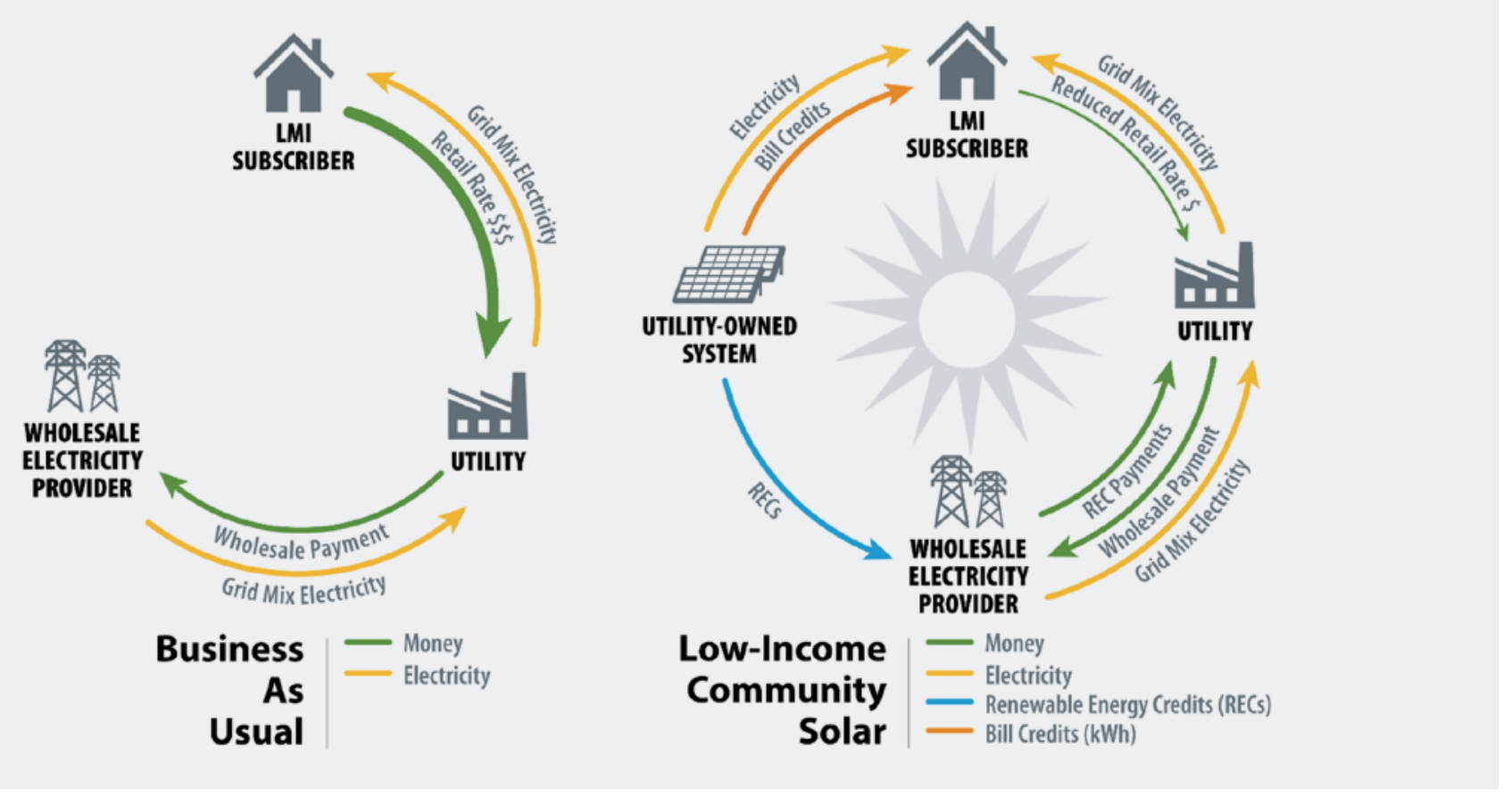

Figure 2. Utility Transaction Structure Summary

The factors that contributed to the lower return in these projects are summarized below:

1. Utilities still paid for approximately half of the upfront system cost.

2. Utilities received less revenue from subscribers than they would have under retail rates.

3. Utilities receiving wholesale power from Tri-State were still required to pay for energy generated by the solar system due to their take-or-pay arrangement.

4. Most of the utilities were tax-exempt, and thus were not able to take advantage of federal tax incentives.

5. Given that the projects were relatively small, there were minimal economies of scale.

Figure 3 shows the cash flows of the community solar project, in comparison with cash flows under retail rates (the business as usual case). In year 0 , the utilities paid for the upfront cost of the community solar system. Then, in years 1-20, the utilities are expected to earn lower revenues from the community solar project than they would have under business as usual.

When compared with business as usual, the community solar projects resulted in a decrease in utility returns of $\$ 183,000$ over the course of 20 years, assuming a $5 \%$ discount rate. This means that the projects' return over 20 years, including the cost to purchase the system, was on average $\$ 183,000$ less than if the utilities had not done the projects. Spread evenly over 20 years, this equates to $\$ 9,150$ per year in lower utility net income. However, the returns of future LICS projects will depend greatly on the regulatory framework of each individual utility. For example, if an investor-owned utility had purchased and owned the system, the project return might have been driven more by the capital cost of those assets than the difference in revenues, due to investorowned utilities' ability to receive regulated returns based on their total assets. ${ }^{9}$ The regulatory environment will greatly impact the economics of future LICS projects.

\section{Factors Influencing Utility Return}

There are numerous factors influencing a LICS project's return, and these factors will vary considerably depending on the region and project requirements. The relative hypothetical impact of capital costs, federal tax incentives, and debt financing on a solar project's levelized cost of energy (LCOE) are summarized in Figure 4. Although the cost of debt financing is also a major driver of solar project costs, the cooperatives funded the projects with their own capital and did not use any financing. However, the cost of energy is only half of the picture; project returns are also largely determined by the revenues earned by the project (for example, subscriber payments and renewable energy credits). A sensitivity analysis of the hypothetical impact of several of these major factors on utility return - subscriber credits, capital costs, and federal tax incentives - is included below.

\section{Impact of Credit Discount}

Although capital costs and incentives are an important component of the overall project returns, the level of solar credit had the largest impact on the overall utility return for the projects. Compared to business as usual, the community solar return would have decreased by roughly $\$ 134,000$ between a $20 \%$ and $60 \%$ subscriber discount. The projects were unable to

9. For more information on utility regulation, see: Electricity Regulation in the U.S.: A Guide (Lazar, 2016). 


\section{Business as Usual vs. Community Solar Case (Cash Flow Comparison)}

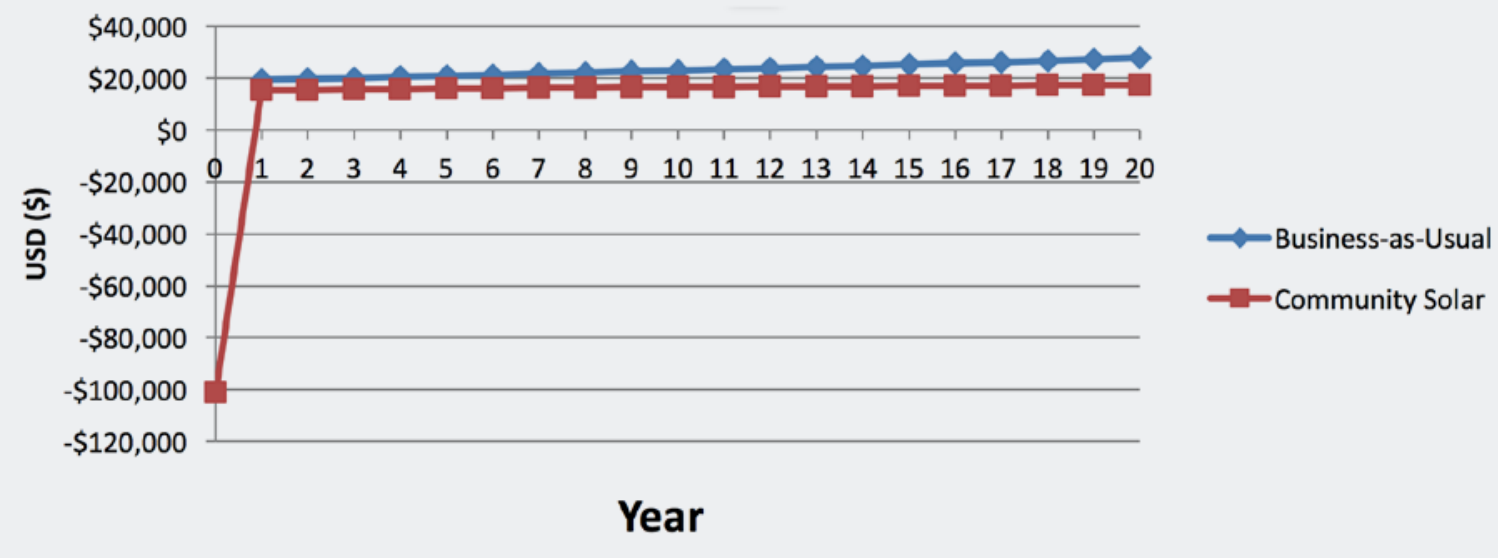

Figure 3. Community Solar Cash Flow Comparison

provide a greater than $60 \%$ discount to LMI customers because they only credit the variable per-kWh rate, and excluded the fixed charges that comprised the remainder of customers' bills.

Since one objective of LICS projects is to lower the energy burden for LMI households, it is important to recognize that larger subscriber credits must be offset by other revenues or cost savings. These could include tax incentives, renewable energy credit (REC) payments, demand charge savings, avoided wholesale power costs, or community solar incentives, to name a few.

Key Takeaway: There is a tradeoff between the level of assistance for LMI households and utility returns. Offering larger discounts to LMI subscribers results in lower utility revenues in comparison to what they would have received under business as usual. This gap in revenue must be absorbed by the utility, or otherwise covered by additional incentives or community solar project revenue.

\section{Capital Costs}

One major driver of the utilities' return on the projects was the initial capital investment in the project. One of the utilities provided in-kind contributions, such as land for the solar system, and did not pay any upfront cost for the system, which resulted in a much higher return for that project in comparison to the other utilities that paid for up to $50 \%$ of the project cost. The systems' total installed costs also varied considerably, from $\$ 1.57 / \mathrm{W}$ to $\$ 3.75 / \mathrm{W}$ between the lowest and highest cost systems.

Because each utility project provided different subscriber credits, the LMI subscribers' year-one bill savings were standardized to $30 \%$ for all six utility projects to control for this variable. Then, because the system costs varied, the impact of potential system cost reductions between $0 \%$ and $50 \%$ of the capital costs for each project was examined. A 50\% reduction in the initial capital cost resulted in an increase of up to $\$ 50,000$ in project returns. Although this 50\% capital cost reduction did not have as significant of an impact on the projects as expected, this was partially due to the fact that the upfront capital costs of the projects were subsidized by CEO funding. If a future project's upfront costs were not subsidized, system cost reductions would likely play a larger role in the overall project return.

Key Takeaway: Despite reductions in solar project costs, capital costs are still a major factor in project returns. Reducing the upfront cost of a solar system is one of the best ways to increase overall project solar returns. However, reducing capital costs is less important if the system's cost is partially subsidized. One limitation for LICS projects was that their median project size was $148 \mathrm{~kW}$; $M W$-scale projects tend to be cheaper due to economies of scale, and are better able to attract tax equity investment.

\section{Federal Tax Incentives}

Another major impact on a project's return is the inclusion of the federal tax credit and accelerated depreciation benefits for solar projects. The federal tax credit is currently $30 \%$ of the system's total qualified basis, subject to a periodic stepdown and eventually reaching $10 \%$ by 2022 , whereas the accelerated depreciation allows a project owner to fully depreciate the asset for tax purposes in the first five years. A unique feature of the rural electric cooperatives involved in these projects was the fact that they are tax-exempt entities, and therefore were not able to take advantage of these incentives. If the cooperatives had been taxable entities, these incentives would have provided an average $\$ 123,000$ benefit to their projects, assuming a $40 \%$ tax rate and sufficient tax appetite, but would have also had to pay taxes, which could reduce this benefit.

Although most of these projects were too small to attract tax equity interest, projects under $1 \mathrm{MW}$ could still potentially pursue PPA transactions where a taxable third party owns the 


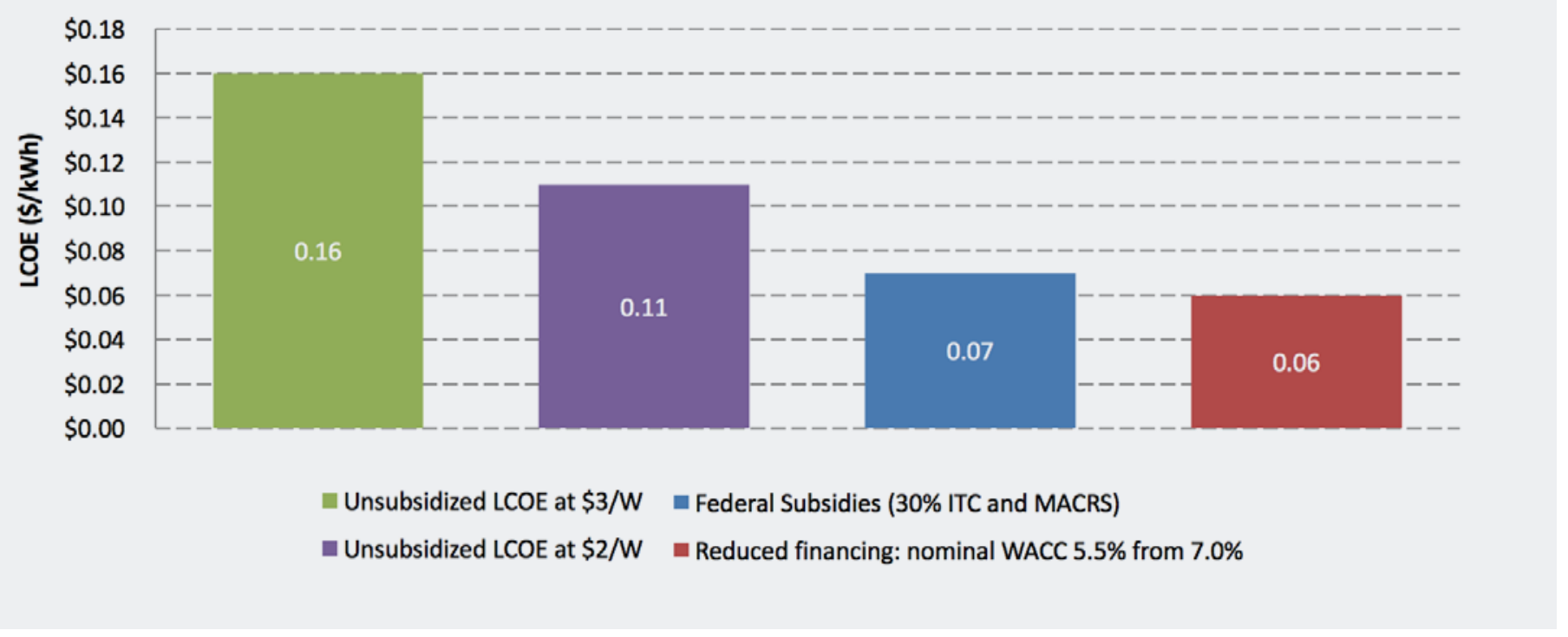

Figure 4. Drivers of Solar Project LCOE

system and takes the tax benefit and passes on some of this value to the tax-exempt utility. For additional information on the tax incentives, refer to the SEIA Guide to Federal Tax Incentives for Solar Energy. ${ }^{10}$

Key Takeaway: Tax incentives can be a major source of value to a community solar project. However, transaction costs, such as the legal fees and financial due diligence required to partner with tax equity investors, can be significant, making it difficult or uneconomical to pursue this option at smaller project sizes. It should also be noted that tax equity investors may not be required if a taxable utility has sufficient tax liability to utilize the incentives themselves. Smaller projects without taxable owners may not be able to take advantage of the tax incentives, but could potentially partner with a taxable third party under a PPA.

\section{Synthesis}

If the tradeoff between utility returns and LMI subscriber discounts is not anticipated, utilities or developers may see significant losses from supporting an LMI project, which may ultimately discourage utilities and developers from completing more LMI projects in the future. Balancing the project's financial viability, while still providing a meaningful reduction of LMI household's energy burden, is essential to creating a replicable LICS program.

Using the data from the six utilities included in the financial analysis, the tradeoff between increasing subscriber discounts and decreasing utility returns, in comparison to business-as-usual, is shown in Figure 5. This figure shows what subscriber discounts and incentives would be required for a low-income community solar project to "break even" by earning the same return as under business as usual. To achieve a similar return for the utilities as under business as usual (with similar CEO grant funding), it was estimated that if subscribers received a $10 \%$ to $20 \%$ reduction on their utility bill, and the utilities partnered with a tax equity investor to take advantage of the federal tax incentives, they would earn a return similar to what they would have earned under their standard rates. PVREA broke even while providing a $30 \%$ bill reduction to subscribers because it received REC payments, and received economies of scale from its larger system size. It should be noted that the value of the tax incentives to the project owner under a tax equity arrangement is subject to negotiation, and the assumed benefit below represents the upper limit that could potentially be monetized.

Using the costs and financial data provided by six of the participating utilities, the red columns in Figure 5 show the estimated average decrease in net income (on a net present value basis), if the utility projects had all provided a subscriber discount between $0 \%$ and $60 \%$ (but did not utilize the federal tax incentives). The columns in blue show the same average difference in net income, but also assume that the utilities were able to partner with a tax equity investor that could fully utilize the federal tax incentives. The NPV metric accounts for the discounted value of future cash flows, and is a metric of the profitability of a project.

It should be noted that a $10 \%$ to $20 \%$ discount will most likely not significantly reduce the energy burden of LMI households. In the case of the Demonstration Program, utilities set their own project goals, with most aspiring to provide a subscriber with cost savings of about $50 \%$.

In the future, where utilities are unable or unwilling to accept a lower return in comparison to business as usual, other sources of funding (such as state incentives), lower project costs, and/or other innovations would be required to achieve larger subscriber discounts.

10. Martin, K. SEIA. "Guide to Federal Tax Incentives for Solar Energy." https://www.seia.org/solar-tax-manual 


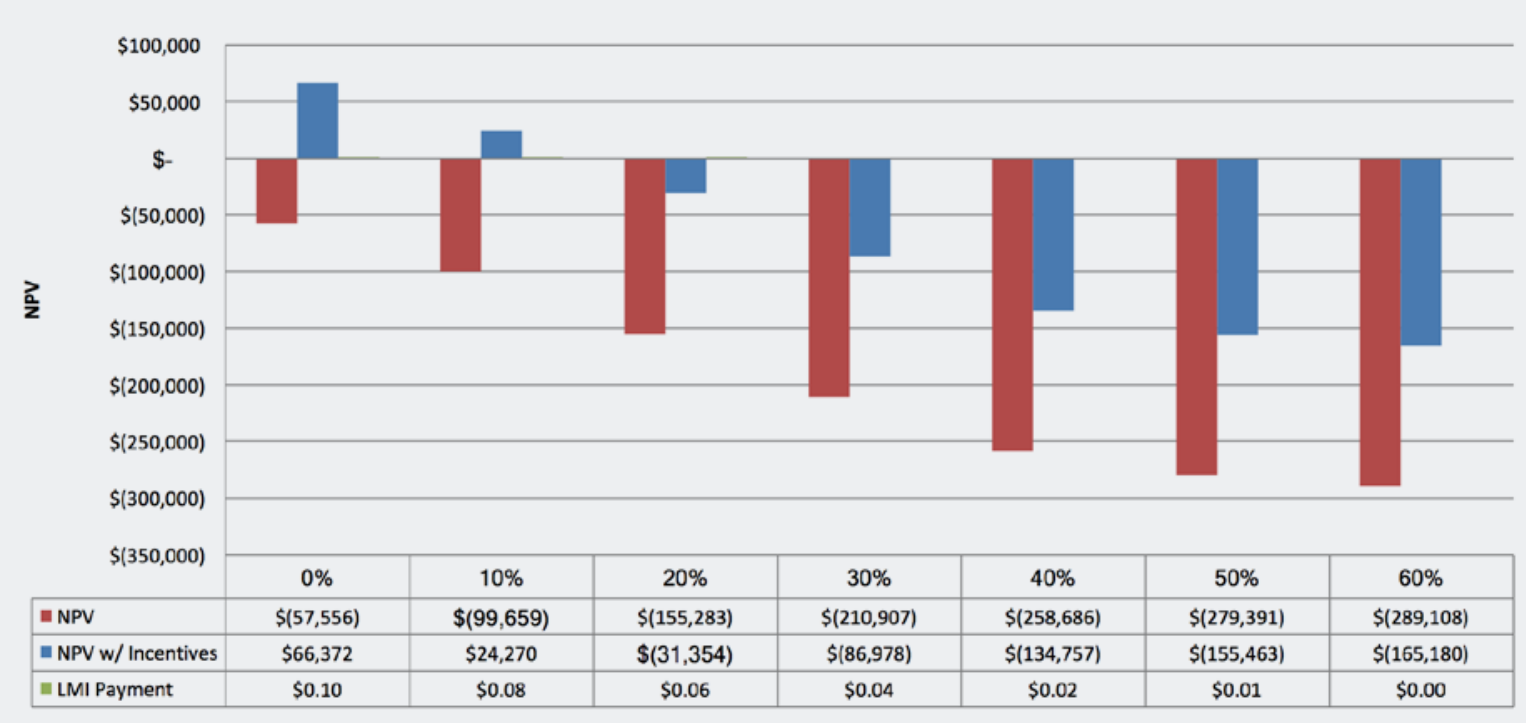

Figure 5. Community Solar NPV Breakeven with Tax Incentives

\section{Third-Party-Led LMI Solar Approach}

Most of the utility projects in the program were $100 \%$ subscribed by low-income households, which impacted a much broader number of LMI customers, but also required additional grant funding. The one exception was PVREA, which subscribed $36 \%$ of its $\sim 2$-MW PV system to LMI households $(700 \mathrm{~kW})$. In addition to these utility-led approaches, there are also third-party-led LMI community solar approaches that involve a non-utility entity developing the project and selling the electricity and renewable energy credits to either a utility or directly to households. Although third-party-led projects have not generally included $100 \%$ LMI members, they could potentially adopt this approach in the future. There are two main third-party-owned approaches to LMI participation in community solar in the United States:

- Carve-outs: Required LMI subscriber participation levels of typically $5 \%$ to $20 \%$ of the system capacity for all community solar projects.

- Subsidies: Existing incentives for solar systems for LMI households (e.g., low-interest financing, developer incentives for including LMI households, etc.) are present in certain states.

An advantage of these approaches is that it allows a third-party developer to achieve larger project scales and attract tax equity. As demonstrated in the PVREA community solar project, another option is to include a mix of higher-income subscribers who may be willing to pay more for their shares, along with a large proportion of LMI subscribers, potentially obviating the need for subsidies to make a project economically viable.

Currently, there are five major state markets expected by GTM Research to drive the majority of third-party-led community solar: Colorado, Massachusetts, Minnesota, New York, and Maryland. ${ }^{2}$ In addition, there are currently 14 states (and the District of Columbia) that have adopted community solar policies or incentives programs, as discussed in greater detail on Vote Solar's "Shared Renewables HQ" website. ${ }^{11}$
One disadvantage of a carve-out approach is that third-party developers can struggle to find enough LMI subscribers for each project to meet their LMI targets. ${ }^{12}$ One potential solution is a project portfolio-based carve-out approach that allows a third-party community solar owner to subscribe more LMI households to certain projects that could support the LMI subscriber discount, and less on others.

\section{Conclusion}

The Colorado Low-Income Community Solar Demonstration Program resulted in $1,485 \mathrm{~kW}$ of community solar projects providing bill credits to 380 low-income subscribers. These programs demonstrate that municipal and cooperative utilities can reduce the energy burden of LMI households through dedicated LICS projects and provide several key project structure and financing lessons learned within their particular regulatory context:

- Larger community solar project scales (over $1 \mathrm{MW}$ ) can increase project returns through lower capital costs and the ability to use tax incentives, but also require utilities to recruit and retain a larger number of low-income subscribers.

- There is a tradeoff between increasing subscriber discounts for low-income households and decreasing utility project returns. Although returns for the community solar projects were positive, they were smaller than the returns the electric cooperatives would have earned under business as usual.

- The inclusion of federal tax incentives in the projects can significantly impact project returns, although most of the utilities

11. Vote Solar. "Shared Renewables HQ". http://www.sharedrenewables.org/ community-energy-projects/

12. Lotus Engineering and Sustainability. "Analysis of the Fulfillment of the LowIncome Carve-Out for Community Solar Subscriber Organizations" November 2015. https://www.colorado.gov/pacific/sites/default/files/atoms/files/LowIncome\%20Community\%20Solar\%20Report-CEO.pdf 
involved in the Demonstration Program were tax-exempt, and their projects were too small to take advantage of tax incentives. Cooperatives with smaller projects could potentially partner with a taxable third party under a PPA instead of purchasing their systems outright.

As shown by the Demonstration Program, project structure makes a significant difference in the ultimate utility return and subscriber impact of LICS. By balancing this tradeoff, as well as identifying new revenue streams for LICS projects, a replicable cooperative or municipal utility-led LICS model can be created under which both low-income households and utilities benefit.

\section{Recommendations for Further Study}

One limitation of this analysis is that it looked solely at the project returns of the LICS projects in comparison to the utilities' business as usual case. Evaluating the effectiveness of LICS in comparison to existing bill assistance and weatherization programs would be a logical next step to this analysis. For example, one could compare the subscriber savings under these projects with the subscriber savings from direct bill credits, and determine whether community solar leverages these utility investments more effectively.

In addition, the wholesale costs and demand charges paid by electric cooperatives and municipal utilities may vary significantly between states, which could translate to significant regional differences in the economic viability of future low-income community solar projects. One opportunity for future research could be to identify states with higher wholesale costs and demand charges, where LICS could have higher utility returns.

\section{Glossary}

Community Solar: A solar-electric system (often ground-mounted) that provides power and/or financial benefit to multiple community members. Community solar is typically owned by a utility or a private developer, and sells portions of the array's power $(\mathrm{kW})$ or generation $(\mathrm{kWh})$ to multiple community subscribers.

- Subscriber: Utility customers, such as households or businesses, that have a partial stake in a community solar project (either a share of the system's capacity or production).

- Low- to Moderate Income (LMI): Individuals or families whose household income does not exceed $115 \%$ of the median income for the area, when adjusted for family size. ${ }^{13}$

- Energy Burden: The percentage of gross annual household income that is used to pay annual residential energy bills. In a CEO study, households that pay more than $4 \%$ of their annual income on utility bills are considered energy burdened.
- Demand Charge: Fees applied to the electric bills of commercial and industrial customers based on the highest amount of power drawn during any (typically 15-minute) interval during the billing period.

- Levelized Cost of Energy (LCOE): An economic metric of the total cost to build and operate a power-generating asset over its lifetime divided by the total energy output of the asset over that lifetime, accounting for the time value of money, as well as the costs of fuel, operations, and maintenance.

- Net-Present Value (NPV): The difference between the present value of cash inflows and the present value of cash outflows. NPV is used in capital budgeting to analyze the profitability of a projected investment or project. ${ }^{14}$

- Renewable Energy Certificate (REC): A market-based instrument that represents the property rights to the environmental, social, and other non-power attributes of renewable electricity generation. RECs are issued when one megawatt-hour (MWh) of electricity is generated and delivered to the electricity grid from a renewable energy resource..$^{15}$

- Discount Rate: In this analysis, the interest rate used in discounted cash flow analysis to determine the present value of future cash flows. ${ }^{16}$

- Cost of Capital: The cost of funds used for financing a business. Cost of capital depends on the mode of financing used; it refers to the cost of equity if the business is financed solely through equity, or to the cost of debt if it is financed solely through debt. Many companies use a combination of debt and equity to finance their businesses. Since the cost of capital represents a hurdle rate that a company must overcome before it can generate value, it is extensively used in the capital budgeting process to determine whether the company should proceed with a project. ${ }^{17}$

13. U.S. Department of Housing and Urban Development. "How is a Low to Moderate Income Individual or Family Defined?" https://hudgov.prod.parature. com/link/portal/57345/57355/Article/4684/How-is-a-Low-to-Moderate-Incomeindividual-or-family-defined

14. Investopedia "Net Present Value (NPV)" https://www.investopedia.com/terms/n/ npv.asp\#ixzz $4 y L Y v y 3 X 5$

15. EPA. "Renewable Energy Certificates" https://www.epa.gov/greenpower/ renewable-energy-certificates-recs

16. Investopedia "Discount Rate" https://www.investopedia.com/terms/d/ discountrate.asp

17. Investopedia. "Cost of Capital" https://www.investopedia.com/terms/c/ costofcapital.asp

18. Investopedia "Net Income" https://www.investopedia.com/terms/n/netincome.asp 